\title{
Coating seeds with fertilizer: A promising technique for forage crop seeds
}

\section{Revestimento de sementes com fertilizante: Uma técnica promissora para sementes de forrageiras}

\author{
Danilo Força Baroni ${ }^{1 *}$ (D), Henrique Duarte Vieira1 ${ }^{\text {(iD }}$ \\ ${ }^{1}$ Universidade Estadual do Norte Fluminense Darcy Ribeiro/UENF, Campos dos Goytacazes, RJ, Brasil \\ ${ }^{*}$ Corresponding author: baronidf@gmail.com \\ Received in May 16, 2020 and approved in July 17, 2020
}

\begin{abstract}
Fertilization is not a common management practice at pasture establishment in Brazil. Seed coating technology can be a useful approach to ensure the availability of nutrients to plants during the early stages of development. Thus, the objective of this work was to investigate the incorporation of liquid fertilizer in seeds of Stylosanthes and to evaluate the effect of this technology on seed quality. Mastermins ${ }^{\circledR}$ fertilizer was applied to the last layer of the binder material coating on the seed and Polyseed 76F polymer adhesive was thereafter applied onto the fertilizer. Physiological and biometric analyses of the seeds were carried out. Six fertilizer doses (0, 10, 20, 30, 40, and 50 mL.100 g seeds $^{-1}$ ) were tested, with and without adhesive. The control group comprised of uncoated seeds. The method provided a significant increase in the concentration of mineral nutrients supplemented to the seeds, and the use of the adhesive polymer further increased the concentration of minerals. The liquid fertilizer had no effect on seed emergence and emergence speed but influenced germination and germination speed. The results also showed that fertilizer doses higher than $10 \mathrm{~mL} .100 \mathrm{~g} \mathrm{seeds} \mathrm{s}^{-1}$ did not provide higher dry mass accumulation in Campo Grande Stylosanthes.
\end{abstract}

Index terms: Stylosanthes capitata/macrocephala cv. Campo Grande; seed quality; fertilization; polymer adhesive.

\section{RESUMO}

A adubação não é uma prática comum na instalação de pastagem no Brasil. Assim, a técnica do recobrimento de sementes pode ser a alternativa para garantir nutrientes na fase de semeio de forrageiras. Assim o objetivo deste trabalho foi avaliar a incorporação de fertilizante líquido em sementes revestidas de estilosantes e o efeito dessa tecnologia na qualidade das sementes. Foi utilizado o fertilizante Mastermins ${ }^{\circledR}$, aplicado na última camada do revestimento e o polímero adesivo Polyseed 76F, aplicado após o fertilizante. Foram realizadas análises fisiológicas e biométricas das sementes. Utilizou-se 6 doses de fertilizante (0,10, 20, 30,40 e $50 \mathrm{~mL}$. $100 \mathrm{~g}$ sementes ${ }^{-1}$ ), com e sem polímero, além do tratamento controle (semente não revestida). A metodologia proporcionou um aumento significativo nas concentrações dos nutrientes minerais nas sementes, ressalvando que, a adição de polímero adesivo aumentou ainda mais a concentração dos mesmos nas sementes. Além disso, a aplicação de fertilizante líquido não interferiu na emergência e velocidade de emergência das sementes, apenas na germinação e na velocidade de germinação. Foi possível verificar também que, doses de fertilizante superiores a $10 \mathrm{~mL} .100 \mathrm{~g}_{\text {sementes }}{ }^{-1}$ não propiciaram maior acúmulo de massa seca em plantas de estilosantes Campo Grande.

Termos para indexação: Stylosanthes capitata/macrocephala cv. Campo Grande; qualidade de sementes; fertilização; polímero adesivo.

\section{INTRODUCTION}

Intercropping Fabaceae and Poaceae has several advantages over sole cropping. Fabaceae is generally characterized by the ability to fix atmospheric nitrogen and produce biomass with high protein content and contribute to sustainability and the recovery of degraded pastures.

In Brazil, fertilization is not a common pasture establishment and management practice. The coating of seeds with fertilizer can supply essential nutrients to assist growth in the early stages of plant development, thereby playing a role in the successful establishment of forage.

Scientific literature is scarce on nutrient coating. Most studies are related to the addition of micronutrients such as zinc, boron, and molybdenum to the coating (Albuquerque et al., 2010; Xavier et al., 2016; Acha; Vieira; Freitas, 2016). However, many other nutrients are essential 
for the development of plants and could be incorporated in the coating. Studies are also scarce on dosages of nutrients to be used in seed coating formulations and the application techniques.

In addition, there is a possibility of adding effective adhesive polymers to the coating formulations, without impairing seed germination (Accinelli; Abbas; Shier, 2018). The polymer forms a thin layer that adheres to the seed surface, thereby increasing fertilizer adherence and protecting fungicides and insecticides applied to the seeds (Kunkur et al., 2007), consequently reducing losses. In this context, the objective of the present study was to evaluate the quality of Campo Grande Stylosanthes seeds coated with different fertilizer doses, with or without the addition of adhesive polymer.

\section{MATERIAL AND METHODS}

Commercial seeds of Stylosanthes capitatel macrocephala $\mathrm{cv}$. Campo Grande were used for the experiment. The seeds were mechanically scarified with 100-grit sandpaper to break the integumentary dormancy.

The pasture foliar fertilizer Mastermins ${ }^{\circledR}$ was used at different doses for seed coating. The fertilizer formulation contains Nitrogen $(3 \%), \mathrm{P}_{2} \mathrm{O}_{5}(15 \%), \mathrm{K}_{2} \mathrm{O}$ (8\%), Magnesium (1\%), Boron (0.2\%), Copper ( $0.3 \%)$, Manganese (1\%), Molybdenum (0.05\%), and Zinc (2.0\%).

Seed coating was carried out using a stainless steel N10 Newpack ${ }^{\circledR}$ coating pan with a tank and a compressed air spray gun to apply the binder solution coupled to a hot air blower. The sand was used as filler for the seed coating. Sand that passed through a $0.25 \mathrm{~mm}$ mesh sieve was washed in tap water for the removal of contaminants and dried in a forced ventilation oven at $105^{\circ} \mathrm{C}$ for $24 \mathrm{~h}$.

Cascorez Extra $\left(\right.$ Henkel $\left.^{\circledR}\right)$, a polymer (polyvinyl acetate - PVA) adhesive, was used as the binder material. It was diluted in water in the ratio of $2: 1$ and heated to $70{ }^{\circ} \mathrm{C}$ for $12 \mathrm{~h}$ before starting the coating process (Baroni et al., 2020).

The coating consisted of 12 layers of the filler. Every layer contained 25 grams $(\mathrm{g})$ of the binder, applied in two portions of $12.5 \mathrm{~g}$ each.

The seeds were placed into the coating pan, and the filler material was added. The pan was set at $77 \mathrm{rpm}$, and the binder solution was pumped at a pressure of 4 bar. After each portion of the filler was added, the binder solution was applied for three seconds. After adding the second portion of the filler, the hot air blower was operated at $50{ }^{\circ} \mathrm{C}$. This procedure pertained to the coating of one layer. The entire procedure was repeated 12 times to complete the coating. The hot air blower operated at $50{ }^{\circ} \mathrm{C}$ for three minutes for the first two layers and two minutes for the remaining layers of the coating.

The liquid fertilizer Polyseed $76 \mathrm{~F}$ was added to $100 \mathrm{~g}$ of coated seeds over the last layer, $24 \mathrm{~h}$ after the completion of the coating. This was the minimum time necessary to ensure total drying of the coating, avoid the agglomeration of pellets, and facilitate the movement of the coated seeds in the coating pan.

For each $10 \mathrm{~mL}$ of fertilizer applied, a hot air blower was turned on for one minute at $50{ }^{\circ} \mathrm{C}$ to dry the fluidized coater. After the addition of the fertilizer, the seeds were placed in an air-ventilated oven at $30{ }^{\circ} \mathrm{C}$ for $24 \mathrm{~h}$ for drying. Then, the seeds were put back into the coating pan and sprayed with 2 two-second sprays of the polymer (PVA) adhesive. After the first spray was applied, the hot air blower was turned on for one min at $50{ }^{\circ} \mathrm{C}$ and after the second spray for $1.5 \mathrm{~min}$.

Finally, the seeds were spread on a bench at room temperature for $24 \mathrm{~h}$ and stored in multilayer bags at room temperature $\left( \pm 25^{\circ} \mathrm{C}\right)$.

To evaluate the physiological characteristics, germination test and germination speed index (GSI) were performed in the laboratory, and emergence test and emergence speed index (ESI) in the greenhouse, according to the recommendations of the Rules for Seed Testing (Brazil, 2009). GSI and ESI were calculated using the equation proposed by Maguire (1962).

The morphological measures area (AR) and root volume (RV) were scanned and analyzed using the WinRHIZO software.

Shoot dry mass (SDM) and root dry mass (RDM) were determined in plants derived from the emergence test in greenhouse. The plants were dried in an air ventilation oven at $65^{\circ} \mathrm{C}$ for $72 \mathrm{~h}$, cooled down, and weighed on an analytical balance $(0.0001 \mathrm{~g})$.

Sulfuric acid-hydrogen peroxide digestion by the Nessler method (Jackson, 1958) was used for nitrogen determination, and the other elements were determined by nitric digestion and extract reading was taken by an atomic emission spectrometer-ICPE-9000.

The experiment in the laboratory was done in a completely randomized way whereas the one in the greenhouse had a $2 \times 6$ factorial randomized block design, with six fertilizer doses $(0,10,20,30,40$, and 50 $\mathrm{mL}$ per $100 \mathrm{~g}$ seeds) with or without the application of PVA adhesive. There was also a control treatment group (scarified and uncoated seeds).

Lilliefors, Cochran, and Bartlett tests used to verify normality and homogeneity of variances indicated the need 
for the arcsine square root transformation for percentage data of the variables germination and emergence. The other variables described were transformed by the square root of the function $(x+1)$. Data were analyzed by analysis of variance $(\mathrm{p} \leq 0.05)$ and mean comparison Tukey test $(p \leq 0.05)$. The variables in the study were analyzed by the analysis of variance for the determination of the polynomial effect. The results were presented as unprocessed means and standard error of sampling. The software program used to analyze the data was SAEG 9.1 (UFV, 2007).

\section{RESULTS AND DISCUSSION}

Figures 1 and 2 show the linear, quadratic, and cubic effects of the fertilizer dose, applied to seed coating, on the content of nutrients. The content of nutrients in the seeds treated with polymer adhesive was higher than in those without polymer adhesive. The polymer adhesive provided higher adhesion of nutrients to the coating, thereby reducing losses by friction between seeds and, consequently, increasing nutrient concentration.

Pereira et al. (2007) reported similar results using film-coating and chemical treatment on soybean seeds. Treatment with the film polymers AGL 205 or AGL 202 had no effect on the physiological quality of the seeds, whereas they promoted adhesion of fungicide.

Among the nutrients in the fertilizer formulation, only nitrogen (Figure 1) followed a cubic regression. It is possible that nitrogen did not adhere well to the coated seeds, and the friction between them led to losses. However, in the group treated with polymer adhesive, nitrogen adhered to the seeds, and hence the nutrient concentration increased with an increase in the dose of nitrogen.
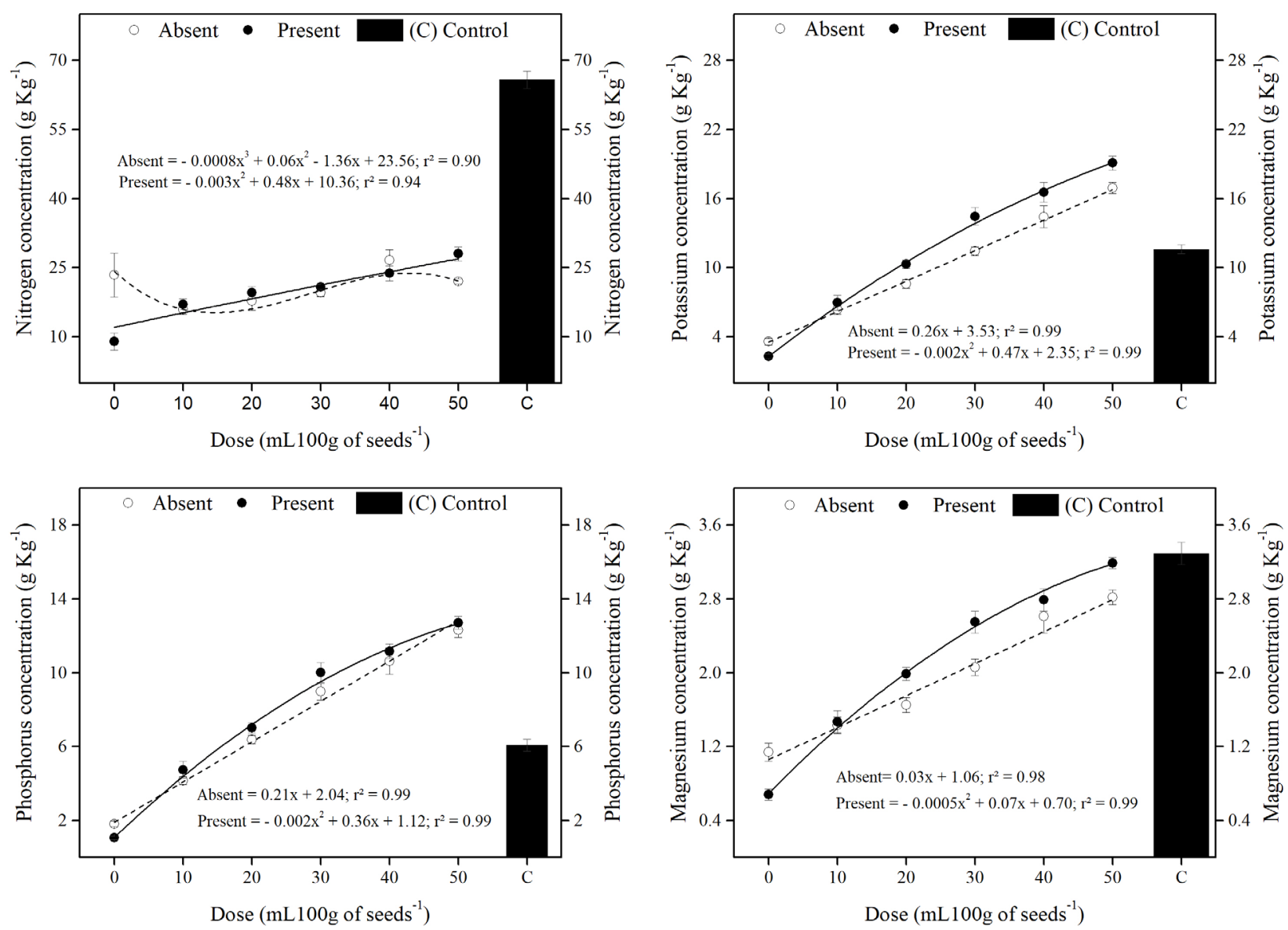

Figure 1: Concentration of macronutrients as a function of fertilizer doses $(0,10,20,30,40$, and $50 \mathrm{~mL} 100$ $\mathrm{g} \mathrm{seeds}^{-1}$ ) and the application of polymer adhesive (Present and Absent) in coated seeds of Campo Grande Stylosanthes. C (Control): uncoated seeds, without fertilizer and poly mer adhesive. 

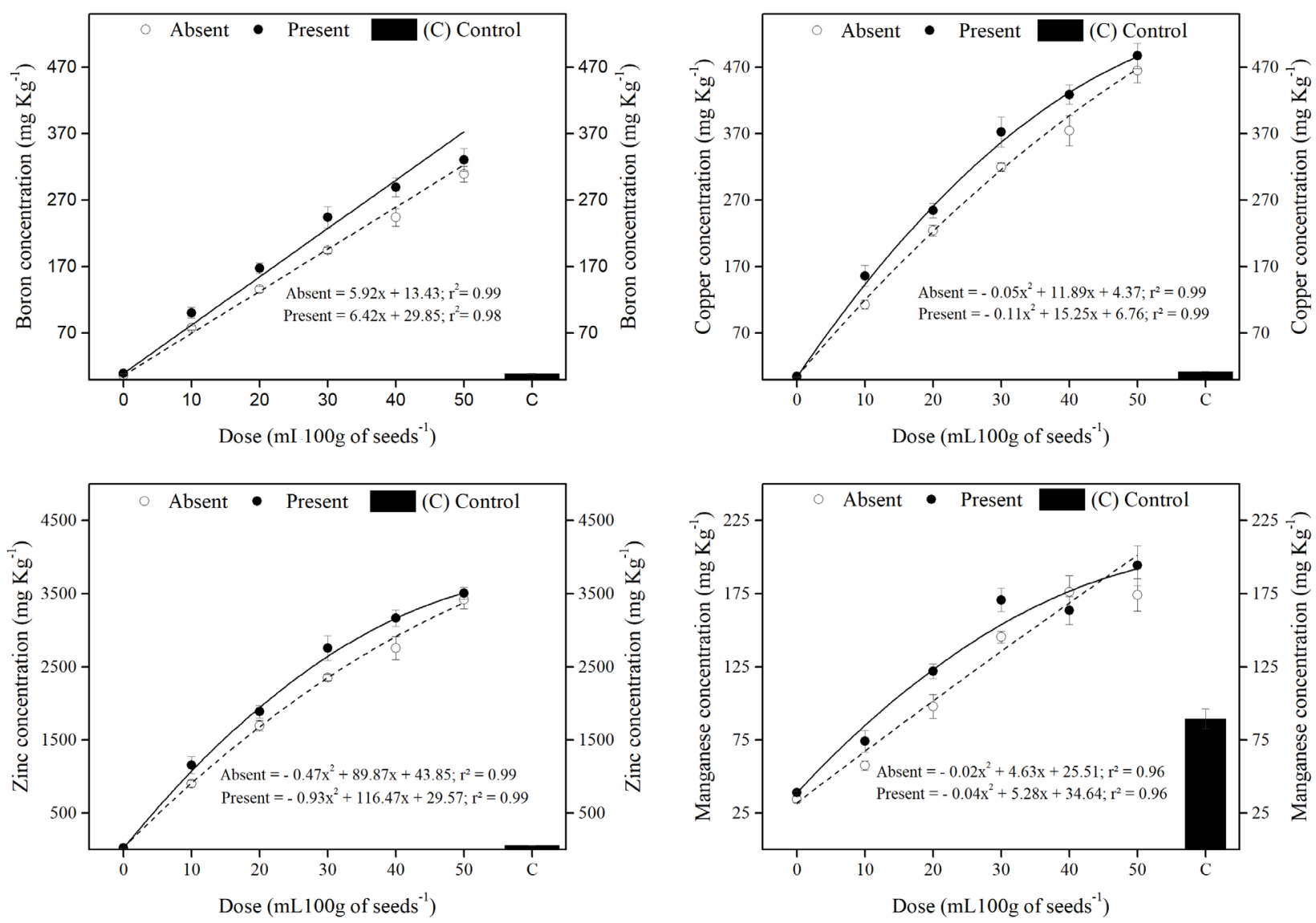

Figure 2: Micronutrient concentration as a function of fertilizer doses $\left(0,10,20,30,40\right.$, and $\left.50 \mathrm{~mL} .100 \mathrm{~g} \mathrm{seeds}^{-1}\right)$ and application of polymer adhesive (Present and Absent) in coated seeds of Campo Grande Stylosanthes. C (Control): uncoated seeds, without fertilizer and polymer adhesive.

In many cases, the control group presented higher nutrient concentration as compared to some treatment groups. This occurred because the same mass of material was used in the analysis between the treatments. The coating has inert material in its composition, which contributed to reduced nutrient content in the seeds. That is, the sample used for the nutrient analysis of the coated treatments contained seed plus coating material, while the sample for the nutrient analysis of the control contained only seed.

Figures 1 and 2 also show the efficiency of the method used for the application of fertilizer to the seeds. An equivalent effect of fertilizer dose on the nutrient concentration was observed, as the increase in the fertilizer dose led to an equivalent increase in nutrient concentration in the seeds.

The highest fertilizer dose led to an increase of \pm 680 and $\pm 700 \%$ in the concentration of phosphorus in the seeds coated with fertilizer without and with polymer adhesive, respectively, indicating that there was a higher adhesion of phosphorus to the seed coat in the latter group.

Phosphorus is considered an essential element. It participates in a number of reactions and is found in various compounds that are vital to plant. Hence, phosphorous is irreplaceable by any other element, as plants cannot complete their life cycle without it (Almeida Júnior et al., 2009). However, the availability of phosphorus is low in tropical soils (Silva et al., 2011) and then, the presence of phosphorus in the seed coat may ensure its availability in the early stages of the seedling growth.

Potassium concentration in seeds of Campo Grande Stylosanthes also increased with an increase in fertilizer doses in the coating. Potassium concentration increased by more than $450 \%$ in seeds that received the highest fertilizer dose irrespective of the application of polymer adhesive. 
Potassium is also an essential nutrient for plant development. Because of its capacity to activate a multitude of enzymes, it is indispensable for metabolic reactions (Maathuis, 2009).

Micronutrient adhesion (Figure 2) followed the same pattern as macronutrient adhesion, i.e., an increase in fertilizer dose led to higher nutrient concentrations in the seeds. However, the increase in micronutrient concentration, from the lowest dose $(0 \mathrm{~mL})$ to the highest dose $(50 \mathrm{~mL})$, was significantly greater than in macronutrient concentration.

The analysis of boron showed that its concentration in seeds coated with $50 \mathrm{~mL}$ Mastermins ${ }^{\circledR}$ was $\pm 309 \mathrm{mg}$ $\mathrm{Kg}^{-1}$ and $\pm 330 \mathrm{mg} \mathrm{Kg}^{-1}$ without and with polymer adhesive, respectively. On the other hand, at the lowest dose $(0 \mathrm{~mL})$ and without polymer adhesive, the concentration of boron was found to be $6.44 \mathrm{mg} \mathrm{Kg}^{-1}$. That means the application of $50 \mathrm{~mL}$ fertilizer provided an increase of $\pm 4,800$ and $5,000 \%$ in the boron concentration in the seeds without and with polymer adhesive, respectively when compared with the $0 \mathrm{~mL}$ dose.

Boron is a constituent of several physiological processes occurring within the plant such as ionic absorption, carbohydrate transport, synthesis of lignin, cellulose, nucleic acids, and proteins (Alleoni et al., 1998). When applied through seed coating, it improves leaf elongation, emergence and tillering, and helps maintain tissue water status (Rehman; Farooq, 2013).

Zinc $(\mathrm{Zn})$ presented the highest concentration in the coated seeds, which is due to its higher concentration in the fertilizer composition. The $50 \mathrm{~mL}$ dose of fertilizer, with or without the polymer adhesive, provided a zinc concentration 150 times higher than the $0 \mathrm{~mL}$ dose without the application of polymer adhesive and 60 times higher than the control.

Very low availability of $\mathrm{Zn}$ is often found in intensively cultivated soils, which leads, especially in young plants, to deficiency, as the roots do not have access to sufficient soil volumes to obtain the nutrient (Adhikari; Kundu; Rao, 2016). Zinc deficiency leads to less vigorous seedlings (Oliveira et al., 2014).

Copper and molybdenum also showed an increase in their concentrations in seeds with an increase in fertilizer doses. At the $50 \mathrm{~mL}$ dose of fertilizer, regardless of the application of polymer adhesive, the increase in copper and molybdenum concentration was 90 times and 49 times, respectively, in the seeds compared with the $0 \mathrm{~mL}$ dose. A large increase also occurred in relation to the control, achieving concentrations of copper and molybdenum 37 and 18 -fold higher at the $50 \mathrm{~mL}$ dose, respectively.
Molybdenum is an enzyme cofactor for nitrate reductase, xanthine oxidase, aldehyde oxidase, and sulfide oxidase (Ávila et al., 2006). It is also a catalyst of nitrogenase, which transforms atmospheric nitrogen into ammonia (Milani et al., 2008), and hence Mo is vital for nitrogen fixation process.

Manganese is required in photosynthesis and photolysis of water and participates as a component of energy bonds between ATP and the enzyme complex (Ávila et al., 2006).

Thus, although the seed coating technique is generally used for fungicide and insecticide application (Farooq et al., 2012), the enhancement of seeds through fertilizer coating increased the concentration of nutrients, and hence it is an effective way of providing essential nutrients during the initial stages of plant growth.

In Figure 3A, an increasing linear effect of regression of moisture on increasing fertilizer doses was obtained for groups with or without the coating of polymer adhesive. Although moisture gain occurred, at none of the instances, the moisture of the fertilizer- and polymeradhesive-coated seeds exceeded the moisture of the control seeds (without coating, without fertilizer, and without adhesive). This factor is highly important for efficient coating, as an increase in moisture can compromise the physiological quality of seeds.

The lowest moisture content was found in the coated seeds. This occurred because the coating material increased mass without a proportional increase in the amount of water in the seeds (Silva et al., 2017). Figure 3B shows this in relation to moisture of treatments in Figure 3A, after removal of the coating. The application of fertilizer and polymer adhesive increased the moisture content only of the coating material, not affecting the internal moisture. Considering that, after the removal of coating material, the moisture content in these treatment groups did not exceed the moisture content of the control.

The analysis of the data on the physiological characteristics of seeds in Table 1 shows a significant difference $(p \leq 0.05)$ only with respect to germination percentage $(G)$ and GSI.

The layer of polymer adhesive formed on the coating affected the water absorption by seeds and consequently, their germination, and hence, treatment with the adhesive and the $0 \mathrm{~mL}$ dose of fertilizer reduced $\mathrm{G}$ in comparison with the control. Likewise, Benatto Junior et al. (2012) also reported that the germination of low vigor soybean seeds coated with adhesive polymer plus fungicide was significantly reduced, notably at the highest dose of the polymer. 

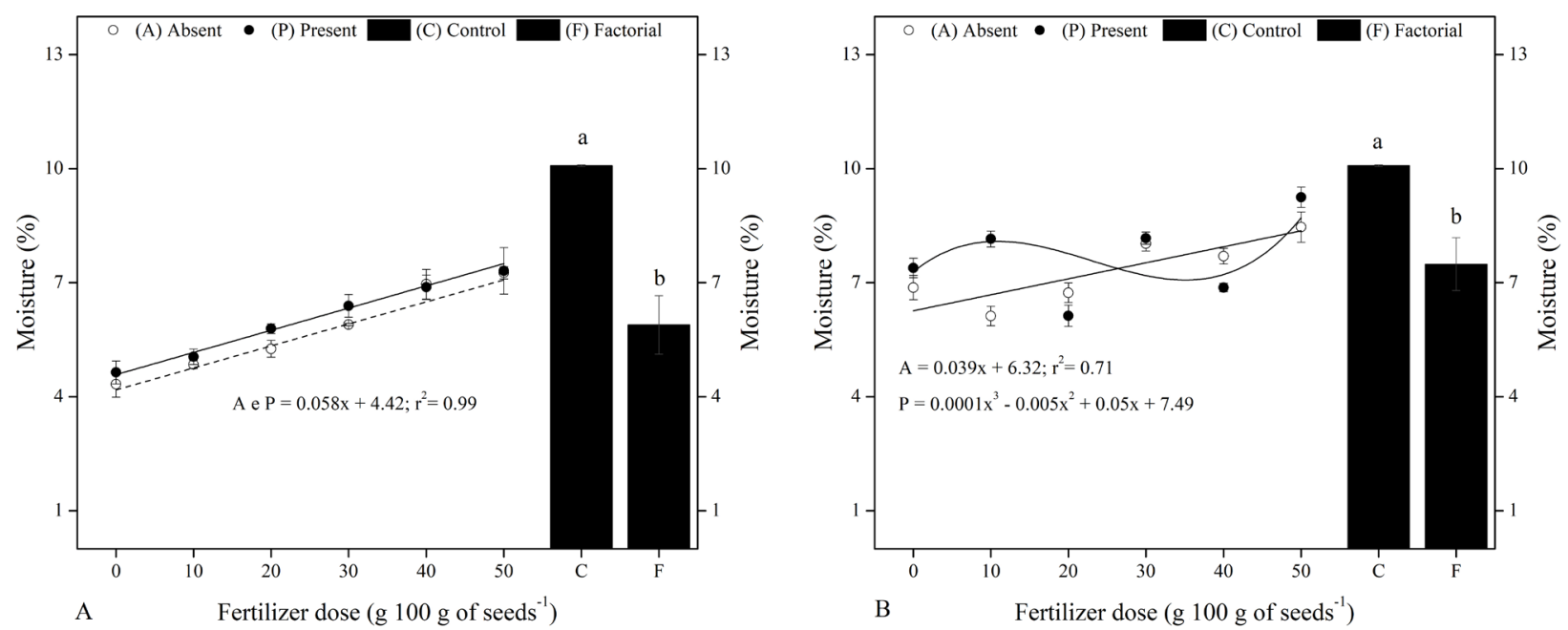

Figure 3: A) Moisture (\%) of Stylosanthes capitata/macrocephala coated seeds after the application of fertilizer and polymer adhesive. B) Moisture (\%) of Stylosanthes capitata/macrocephala seeds after removal of the coating of treatments with fertilizer and polymer adhesive. Absent = without polymer adhesive; Present $=$ with polymer adhesive; $C=$ Uncoated Seed Control. Bars followed by the same small letter are not significantly different by the orthogonal contrast test $(p \leq 0.05)$.

Table 1: Germination percentage (G), germination speed index (GSI), emergence percentage (E), and emergence speed index (ESI) of Campo Grande Stylosanthes coated seeds with the application of liquid fertilizer and polymer adhesive at ten days after germination in laboratory. $\mathrm{FD}=$ Fertilizer dose $\left(\mathrm{mL} 100 \mathrm{~g} \mathrm{seeds}^{-1}\right)$. $\left({ }^{*}\right)$ Means followed by the same capital letters in the column and small letters in the row are not significantly different by the Tukey test $(p \leq 0.05)$.

\begin{tabular}{|c|c|c|c|c|c|c|c|c|}
\hline \multirow{3}{*}{ FD } & \multicolumn{2}{|c|}{ G (\%) } & \multicolumn{2}{|c|}{ GSI (\%) } & \multicolumn{2}{|c|}{$E(\%)$} & \multicolumn{2}{|c|}{ ESI (\%) } \\
\hline & \multicolumn{8}{|c|}{ Polymer adhesive } \\
\hline & Absent & Present & Absent & Present & Absent & Present & Absent & Present \\
\hline Control & $69.0( \pm 2.1) \mathrm{A}$ & $69.0( \pm 2.1) \mathrm{A}$ & $11.4( \pm 0.4) \mathrm{A}$ & $11.4( \pm 0.4) A^{*}$ & $38.0( \pm 4.5)^{\mathrm{ns}}$ & $38.0( \pm 4.5)^{\mathrm{ns}}$ & $6.2( \pm 1.3)^{\mathrm{ns}}$ & $6.2( \pm 1.3)^{\mathrm{ns}}$ \\
\hline 0 & $51.5( \pm 4.6) \mathrm{AB}$ & $45.5( \pm 2.7) \mathrm{B}$ & $8.3( \pm 0.8) A B$ & $7.3( \pm 0.5) \mathrm{B}$ & $33.7( \pm 7.9)$ & $39.7( \pm 6.4)$ & $7.0( \pm 1.9)$ & $8.2( \pm 1.9)$ \\
\hline 10 & $38.0( \pm 3.9) \mathrm{BC}$ & $42.5( \pm 2.7) \mathrm{B}$ & $6.5( \pm 0.7) \mathrm{BC}$ & $7.0( \pm 0.4) \mathrm{B}$ & $39.0( \pm 8.1)$ & $39.5( \pm 8.0)$ & $7.7( \pm 2.5)$ & $7.2( \pm 1.8)$ \\
\hline 20 & $26.5( \pm 4.5) \mathrm{C}$ & $48.5( \pm 5.7) \mathrm{B}$ & $4.07( \pm 0.7) \mathrm{C}$ & $7.3( \pm 1.0) \mathrm{B}$ & $22.2( \pm 3.4)$ & $39.5( \pm 4.8)$ & $4.4( \pm 1.0)$ & $7.5( \pm 1.3)$ \\
\hline 30 & $45.5( \pm 5.7) \mathrm{BC}$ & $43.5( \pm 2.5) \mathrm{B}$ & $7.9( \pm 0.9) \mathrm{B}$ & $6.4( \pm 0.3) \mathrm{B}$ & $32.7( \pm 5.1)$ & $41.7( \pm 4.9)$ & $6.8( \pm 1.7)$ & $7.3( \pm 1.2)$ \\
\hline 40 & $41.0( \pm 5.0) B C$ & $35.0( \pm 7.7) \mathrm{B}$ & $6.4( \pm 0.9) \mathrm{BC}$ & $5.1( \pm 1.30) \mathrm{B}$ & $36.5( \pm 4.7)$ & $37.0( \pm 8.5)$ & $7.5( \pm 1.4)$ & $7.2( \pm 2.0)$ \\
\hline 50 & $29.5( \pm 4.1) \mathrm{C}$ & $44.0( \pm 6.7) \mathrm{B}$ & $4.1( \pm 0.5) \mathrm{C}$ & $6.2( \pm 0.80) \mathrm{B}$ & $34.0( \pm 3.3)$ & $36.0( \pm 10.2)$ & $5.8( \pm 0.8)$ & $6.9( \pm 2.2)$ \\
\hline Mean & $38.6 \mathrm{a}$ & $43.1 \mathrm{a}$ & $6.2 \mathrm{a}$ & $6.5 \mathrm{a}$ & $33.0 \mathrm{~b}$ & $38.9 \mathrm{a}$ & $6.5 \mathrm{a}$ & $7.4 \mathrm{a}$ \\
\hline CV (\%) & 5.5 & 56 & & 1.10 & & 39 & & .07 \\
\hline
\end{tabular}

In spite of the aforementioned drawbacks, several benefits are attributed to coating seeds with polymers, including an increase in seed size and weight, change in shape, reduced loss of products applied to seed surface, improved efficiency and product distribution on seeds, commercial added value, etc. (Ludwig et al., 2011).
The treatments with adhesive coating provided greater germination uniformity and GSI, whereas treatment without adhesive showed greater germination unevenness, to the point of achieving the lowest germination and GSI values for seeds that received fertilizer at the doses 20 and $50 \mathrm{~mL} 100 \mathrm{~g} \mathrm{seeds}^{-1}$. 
As Table 1 shows, at these doses, both germination and GSI were lower than the control and $0 \mathrm{~mL}$ dose in the treatment groups without the application of the polymer adhesive. However, the same doses applied to the treatments with the addition of the polymer differed only in relation to the control.

In seeds with fertilizer coating and without polymer adhesive, the speed of water passage through the coating was probably higher than in the seeds with the adhesive, favoring the movement of nutrients closer to the seed.

Salts have high osmotic potential. High salt concentration near the seeds can cause saline stress and impair germination (Braccini et al., 1996). Some of the authors have reported that saline stress has an osmotic or ionic effect, which can hinder water absorption or favor the entry of ions into cells. Thus, substrate salinity can also affect seed germination (Akbarimoghaddam et al., 2011; Carvalho et al., 2012).

Despite the protective effect of the polymer adhesive observed during seed germination, the methodology for germination tests recommended by the Seed Analysis Rule (Brasil, 2009) presented limitations for coated seeds of Campo Grande Stylosanthes enriched with fertilizer.

A small variation in substrate moisture allowed the solution formed by nutrient dilution to remain in continuous contact with the seeds, which made the environment inhospitable and detrimental to germination.

Acha, Vieira and Freitas (2016) carried out germination tests in the germination box and found that at the highest doses of boron and zinc, the test methodology recommended for uncoated seeds favored the concentration of the salts in the coating after being solubilized.

Therefore, the substrate can exert a direct influence on germination, as its structure, aeration, water retention capacity, among other factors, can favor or hinder seed germination (Guedes et al., 2010).

In the greenhouse experiment, the osmotic effect attributed to the fertilizer did not occur to the point of damaging seedling emergence.

Table 1 also shows no treatment effect on emergence percentage (E) and emergence speed index (ESI), which means that the fertilizer did not affect seedling emergence in greenhouse.

The addition of polymer adhesive only affected the emergence percentage, providing greater seedling emergence. This result reaffirmed the hypothesis that the polymer adhesive may lead to decreased nutrient movement near the seeds.
These results also showed that it was possible to apply fertilizer to the coated seeds without damaging their physiological quality, when sown on a substrate in the greenhouse. Under these conditions, it appears that the seeds were not affected by the osmotic effect of the fertilizer, since the substrate aeration provided good infiltration and movement of water, avoiding the excess of fertilizer around the seeds.

Greenhouses can more accurately represent field conditions, where perforated trays allow leaching of excess salt and moisture (Acha; Vieira; Freitas, 2016). Thus, coating seeds with nutrients becomes a successful technique, as, besides promoting a differential response in relation to untreated seeds, it does not cause impair seed germination and emergence.

The bar charts in Figure 4 show that different treatment doses do not lead to a significant difference in the length and volume of the root, 30 and 90 days after sowing of the seeds in the greenhouse.

Embryos are completely dependent on seed reserves during germination, and so are the seedlings while developing organs for autotrophic resource acquisition (Löwe; Dillenburg, 2011). Therefore, the seed reserve tissue is an important source of nutrients for the plants up to this stage.

However, at 90 days after sowing, the response to some doses of the fertilizer applied to the seeds stood out in relation to the control, despite the lack of statistical difference $(p \leq 0.05)$ between the treatments.

The control plants showed length and root volume of $78.11 \mathrm{~cm}$ and $0.08 \mathrm{~cm}^{3}$, respectively, whereas the plants from treatment with $10 \mathrm{~mL}$ fertilizer without polymer adhesive showed length and root volume of $148.61 \mathrm{~cm}$ and $0.2 \mathrm{~cm}^{3}$, respectively. Thus, an increase of $98 \%$ and $158 \%$ occurred in the variables analyzed, respectively.

A high-density root system has the capacity to exploit larger soil volume and a greater capacity to absorb water and nutrients, and, consequently, greater tolerance to water deficit (Baitelle et al., 2018).

Treatment with $10 \mathrm{~mL}$ dose of fertilizer without the polymer adhesive stood out from the other treatments, as it required a lower amount of fertilizer and promoted root growth equal to the higher dose treatments, besides providing higher root volume to the plants.

Figure 5 shows shoot dry mass (SDM) and root dry mass (RDM) of seedlings of Campo Grande Stylosanthes at 30 and 90 days after sowing the seeds in greenhouse. 

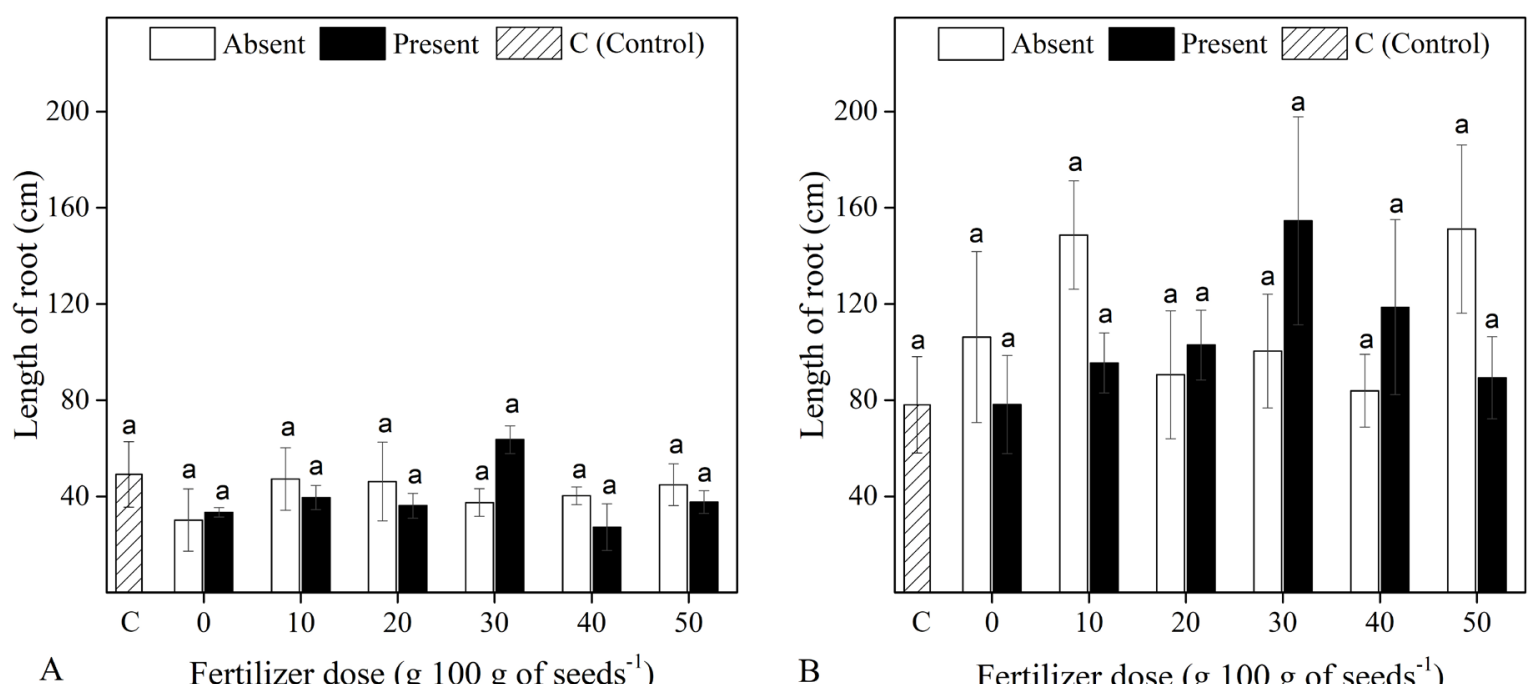

A Fertilizer dose (g $100 \mathrm{~g}$ of seeds $\left.{ }^{-1}\right)$
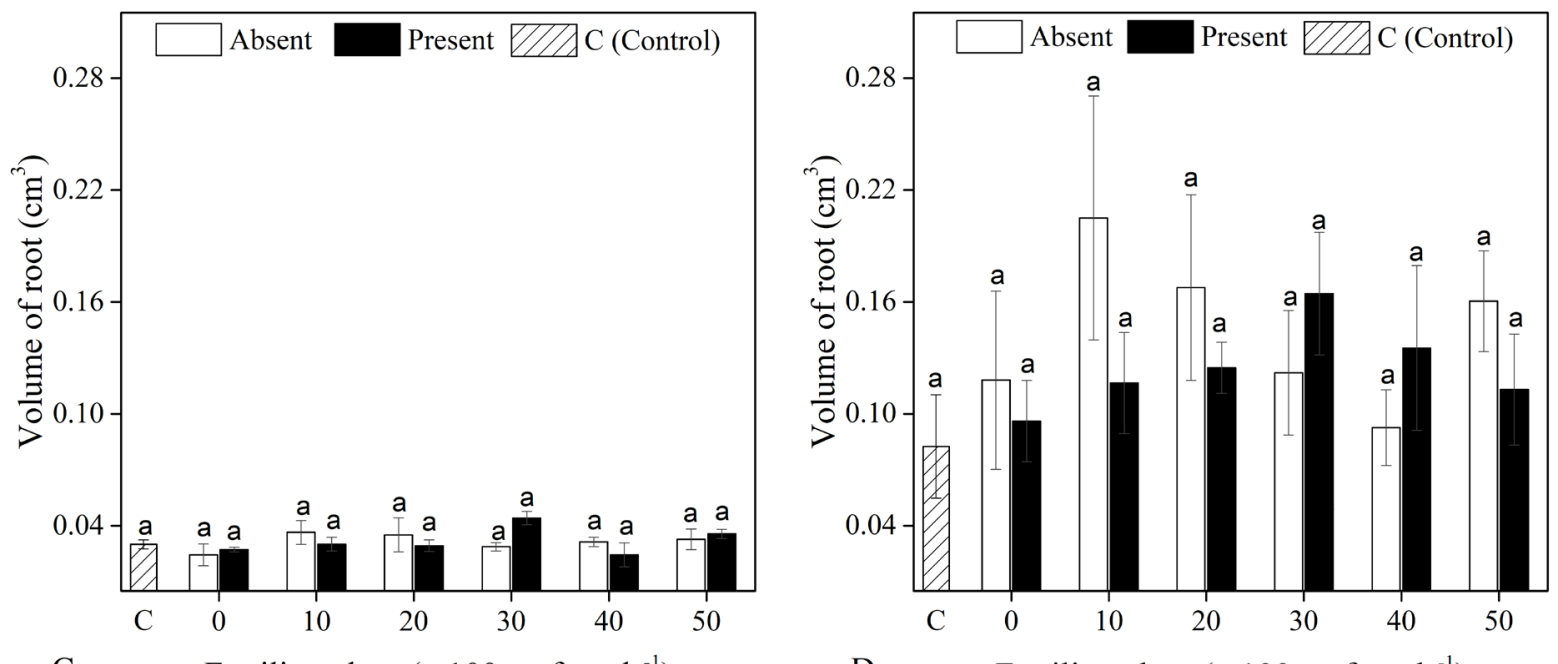

C Fertilizer dose (g $100 \mathrm{~g}$ of seeds $\left.{ }^{-1}\right)$

D Fertilizer dose ( $\mathrm{g} 100 \mathrm{~g}$ of seeds $\left.^{-1}\right)$

Figure 4: Length ( $L$ ) and root volume (VR) of Campo Grande Stylosanthes at 30 ( $A$ and $C$ ) and 90 (B and D) days after emergence in the greenhouse as a function of fertilizer doses and application of polymer adhesive to seeds. Bars followed by the same letter are not significantly different by the Tukey test $(p \leq 0.05)$.

Analysis of data from 30 days after sowing showed no significant difference between SDM and RDM. However, at 90 days, plants originating from the $10 \mathrm{~mL}$ dose treatment, with or without the polymer adhesive, had higher SDM as compared to plants from the zero-dose treatment. There was also a tendency toward higher RDM at the same fertilizer dose.

These results indicate that the application of fertilizer doses higher than $10 \mathrm{~mL}$ to the seeds is unnecessary since this dose allowed the greater accumulation of SDM and a tendency toward higher RDM.

The addition of liquid nutrients to the coating may be an alternative for improving the establishment and growth of plants in the field, as the method of liquid fertilizer application to seeds proved efficient in Campo Grande Stylosanthes. However, further studies are needed for efficient methods of application of liquid fertilizers to seed coating and the doses to be recommended. 

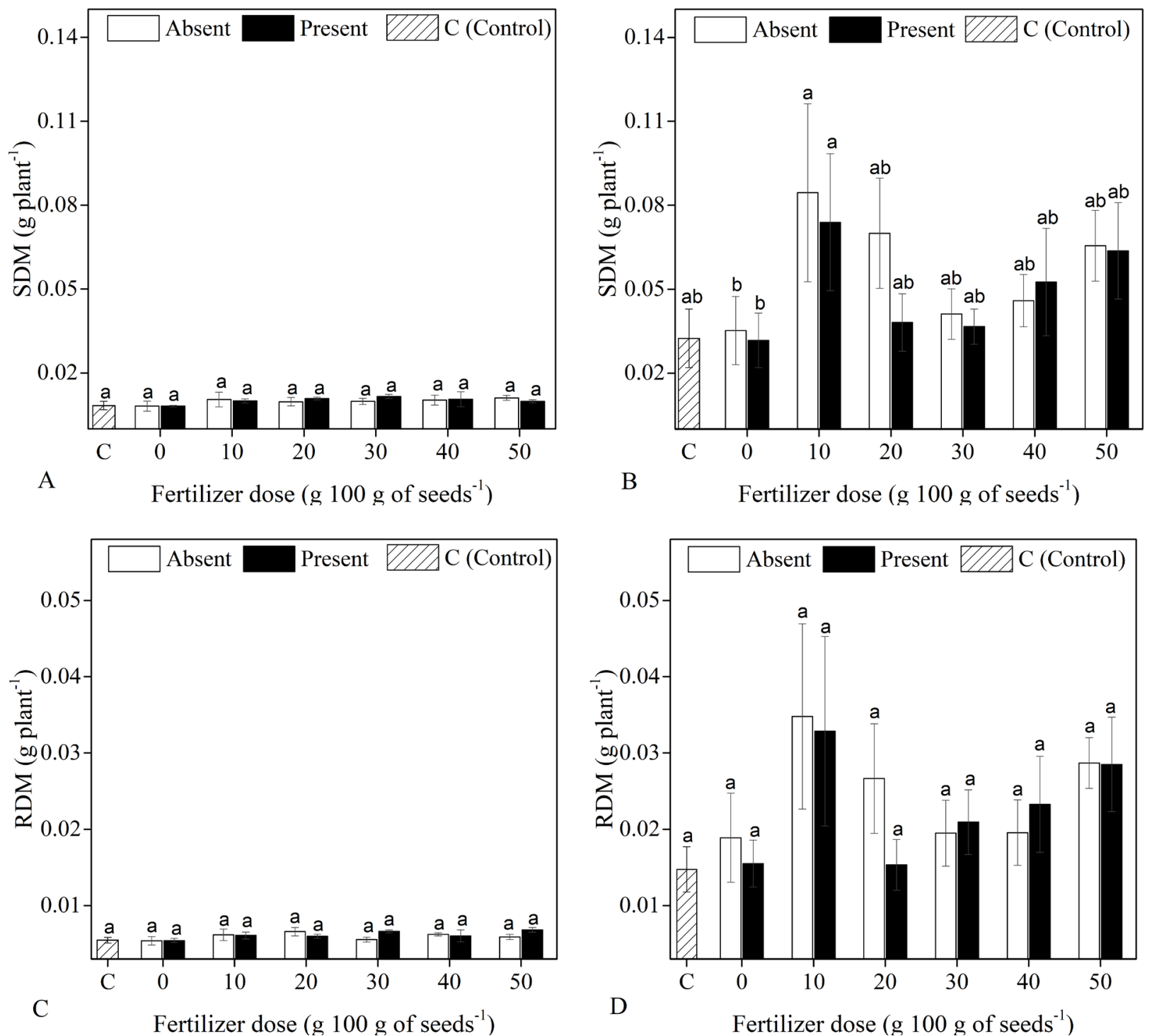

Figure 5: Shoot dry mass (SDM) and root dry mass (RDM) of seedlings of Campo Grande Stylosanthes at 30 (A and C) and 90 ( $B$ and $D$ ) days after emergence in the greenhouse as a function of fertilizer doses and application of polymer adhesive to the seeds. Bars followed by the same letter are not significantly different by the Tukey test $(p \leq 0.05)$.

\section{CONCLUSIONS}

The method of liquid fertilizer application provided adhesion of nutrients to the seeds. Application of the polymer adhesive increased the adhesion of liquid fertilizer to Campo Grande Stylosanthes seeds. The application of the liquid fertilizer did not increase the internal moisture in the seeds, whereas the increase was only observed in the coating. The application of liquid fertilizer impaired germination and GSI but had no effect on the emergence or speed of emergence of Campo Grande Stylosanthes seedlings in the greenhouse. The $10 \mathrm{~mL}$ dose fertilizer provided the highest SDM accumulation in Campo Grande Stylosanthes plants.

\section{ACKNOWLEDGMENTS}

This study was funded by the Coordenação de Aperfeiçoamento de Pessoal de Nível Superior (CAPESFinance code 001) and Fundação de Amparo à Pesquisa 
do Estado do Rio de Janeiro - FAPERJ. The author DFB thanks CAPES for granting the scholarship and State University of North Fluminense (UENF) for learning opportunity.

\section{REFERENCES}

ACHA, A. J.; VIEIRA, H. D.; FREITAS, M. S. M. Perennial soybean seeds coated with high doses of boron and zinc. African Journal of Biotechnology, 15(37):1998-2005, 2016.

ACCINELLI, C.; ABBAS, H. K.; SHIER, W. T. A bioplastic-based seed coating improves seedling growth and reduces production of coated seed dust. Journal of Crop Improvement, 32 (3):318-330, 2018.

ADHIKARI, T.; KUNDU, S.; RAO, A. S. Zinc delivery to plants through seed coating with nano-zinc oxide particles. Journal of Plant Nutrition, 39(1):136-146, 2016.

AKBARIMOGHADDAM, $H$. et al. Salinity effects on seed germination and seedling growth of bread wheat cultivars. Trakia journal of Sciences, 9(1):43-50, 2011.

ALBUQUERQUE, K. A. D. et al. Armazenamento e qualidade de sementes de tomate enriquecidas com micronutrientes e reguladores de crescimento. Ciência e Agrotecnologia, 34(1):20-28, 2010.

ALLEONI, L. R. F.; CAMARGO, O. A.; CASAGRANDE, J. C. Isotermas de Langmuir e de Freundlich na descrição da adsorção de boro em solos altamente intemperizados. Scientia Agricola, 55(3):379-387, 1998.

ALMEIDA JÚNIOR, A. B. et al. Efeito de doses de fósforo no desenvolvimento inicial da mamoneira. Revista Caatinga, 22(1):217-221, 2009.

ÁVILA, M. R. et al. Qualidade fisiológica e produtividade das sementes 73 de milho tratadas com micronutrientes e cultivadas no período de safrinha. Acta Scientiarum Agronomy, 28(4):535-543, 2006.

BAITELLE, D. C. et al. Pit dimensions in the early development of conilon coffee propagated by seeds and cuttings. Journal of Experimental Agriculture International, 20(1):1-8, 2018.

BARONI, D. F. et al. Physical and physiological quality of seeds of Campo Grande Stylosanthes coated with different binder materials. Ciência Rural, 50(4):1-8, 2020.

BENATTO JUNIOR, J. C. et al. Physiological quality of soybeans seeds treated with fungicide and coating with polymers. Revista Brasileira de Ciências Agrárias, 7(2):269-273, 2012.
BRACCINI, A. L. et al. Germinação e vigor de sementes de soja sob estresse hídrico induzido por soluções de cloreto de sódio, manitol e polietileno glicol. Revista Brasileira de Sementes, 18(1):10-16, 1996.

BRASIL. Ministério da agricultura pecuária e abastecimento. Regras para análise de sementes. Brasília: snda/dndv/ clav, 395p, 2009. 398p.

CARVALHO, T. C. et al. Germinação e desenvolvimento inicial de plântulas de soja convencional e sua derivada transgênica RR em condições de estresse salino. Ciência Rural, 42(8): 1366-1371, 2012.

FAROOQ, M. et al. Micronutrients application through seed treatments - A review. Journal of Soil Science and Plant Nutrition, 12(1):125-142, 2012.

GUEDES, R. S. et al. Substratos e temperaturas para testes de germinação e vigor de sementes de Amburana cearensis (Allemão) AC Smith. Revista Árvore, 34(1):57-64, 2010.

JACKSON, M. L. Cation exchange determinations for soils. Soil chemical analysis. New Jersey: Prentice-Hall, p. 73-77, 1958.

KUNKUR, V. et al. Effect of seed coating with polymer, fungicide and insecticide on seed quality in cotton during storage. Karnataka Journal of Agricultural Sciences, 20(1):137139, 2007.

LÖWE, T. R.; DILLENBURG, L. R. Changes in light and nutrient availabilities do not alter the duration of use of seed reserves in Araucaria angustifolia seedlings. Australian Journal of Botany, 59(1):32-37, 2011.

LUDWIG, M. P. et al. Qualidade de sementes de soja armazenadas após recobrimento com aminoácido, polímero, fungicida e inseticida. Revista Brasileira de Sementes, 33(3):395-406, 2011.

MAGUIRE, J. D. Speed of germination-aid in selection and evaluation for seedling emergence and vigor 1. Crop Science, 2(2):176-177, 1962.

MAATHUIS, F. J. M. Physiological functions of mineral macronutrients. Current Opinion in Plant Biology, 12(3):250-258, 2009.

MILANI, G. L. et al. Nodulação e desenvolvimento de plantas oriundas de sementes de soja teores de molibdênio. Revista Brasileira de Sementes, 30(2):19-27, 2008.

OLIVEIRA, S. et al. Tratamento de sementes de Avena sativa I. com zinco: Qualidade fisiológica e desempenho inicial de plantas. Semina: Ciências Agrárias, 35(3):1131-1142, 2014. 
PEREIRA, C. E. et al. Desempenho de sementes de soja tratadas com fungicidas e peliculizadas durante o armazenamento. Ciência e Agrotecnologia, 31(3):656-665, 2007.

REHMAN, A. U.; FAROOQ, M. Boron application through seed coating improves the water relations, panicle fertility, kernel yield, and biofortification of fine grain aromatic rice. Acta Physiologiae Plantarum, 35(2):411-418, 2013.

SISTEMA PARA ANÁLISES ESTATÍSTICAS - SAEG. Versão 9.1. Fundação Arthur Bernardes- UFV, Viçosa, 2007.
SILVA, F. W. A. et al. Germination performance of estilosantes Campo Grande (Stylosanthes capitata/macrocephala) seeds coated with different layers of inert material. American Journal of Experimental Agriculture, 18(4):1-8, 2017.

SILVA, T. O. et al. Plantas de cobertura submetidas a diferentes fontes de fósforo em solos distintos. Semina: Ciências Agrárias, 32(4):1315-1325, 2011.

XAVIER, P. B. et al. Physiological potential of Stylosanthes spp. seeds cv. Campo Grande in response to coating with zinc and boron. Journal of Seed Science, 38(4):314-321, 2016. 